\title{
MAGNETOSTRATIGRAPHY IN ALDEA BRASILERA, ENTRE RIOS, ARGENTINA.
}

J.C.Bidegain'

\section{ABSTRACT}

Upper Cenozoic marine, fluvio-lacustrine and continental-oolian deposits are exposed in river banks and quarries within the province of Entre Rios in northern Argentina. A 26 m sequence from a quarry at Aldea Brasilera has been investigated as to sedimentological and environmental changes, and subjected to paleomagnetic analysis. The magnetostratigraphy established includes six polarity reversals and is interpreted to cover tha last about 3.3 Ma. The deposition of marine and fluvio-lacustrine deposits from 3.3 to about $1.5 \mathrm{Ma}$ seems to have been fairly continuous, whilst the land surfaces and eolian (loess) deposition reflect sporadic deposition. The magnetostratigraphy established may serve as a regional standard section. A final marine transgression of Late Pliocene age is established right on top of the Kaena Reversed Polarity Event. The close association between this geomagnetic event and final marine event may serve as a very useful chronostratigraphic marker level and horizon. It has been recorded in other sections under studies, too.

\section{INTRODUCTION}

The object of this paper is to present the results of paleomagnetic studies carried out on samples from Aldea Brasilera. The site is located at $31^{\circ} 55^{\prime} \mathrm{S}$ Lat. and $60^{\circ} 36^{\circ} \mathrm{W}$ Long. in the province of Entre Rios in northern Argentina (Fig. 1).

Aldea Brasilera may be considered a regional standard section since it includes all paleomagnetic information covering, at least, the last $3.0 \mathrm{Ma}$.

\footnotetext{
'Paleomagnetic Laboratory, Geological Institute, Stockholm, Sweden.
} 


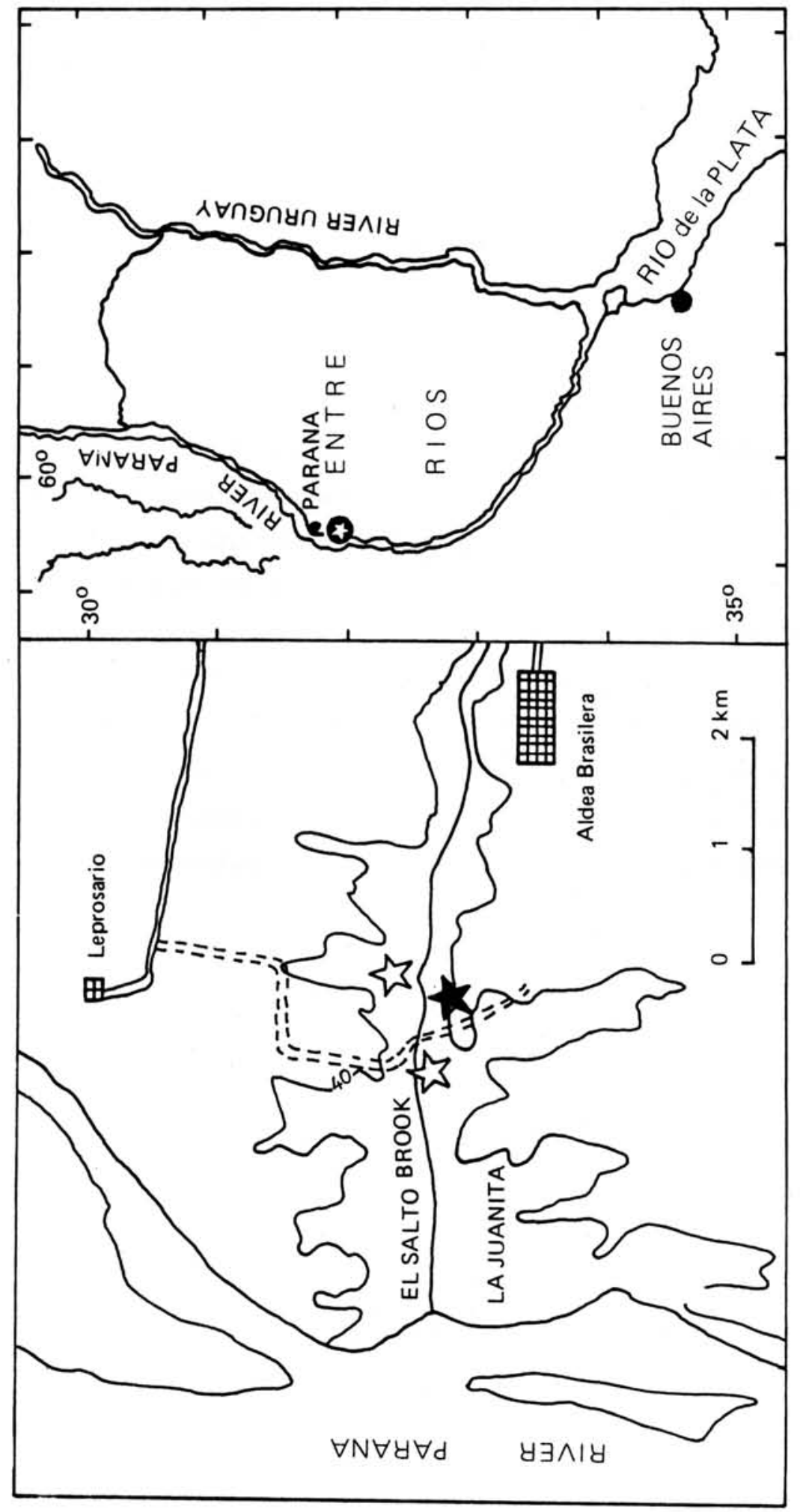

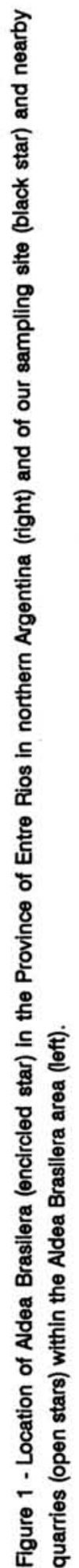


The paleomagnetic sampling was done in Cristamine Quarry. Some other good profiles are exposed in other quarries in Aldea Brasilera, as well as in cliffs at the side of the Parana River (Fig. 1).

The present paper is only a part of a larger project which intends to correlate different exposed units on the base of their paleomagnetic characteristics. The studied region extends from $30^{\circ} 00^{\prime}$ to $36^{\circ} 00$ 'S Lat. and $55^{\circ} 33^{\prime}$ to $62^{\circ} 30^{\prime} \mathrm{W}$ Long.

From the paleomagnetic results, it is possible to state that the Brunhes, Matuyama and Gauss Epochs are registered in the sequence as well as the Olduvai, Kaena and Mammoth Events.

Polarity reversals seem to be independent from stratigraphic boundaries. In the same way, $\mathrm{CaCO}_{3}$ precipitations that occur at different levels are not related to magnetic polarity changes.

For a better understanding of the problem, geologic and stratigraphic information was gathered from bibliography. Besides, records of great numbers of drillings and field observations have been taken into account.

The final result of this research work will enable us to date and correlate Cenozoic sediments in the region, thus contributing to a problem which has not yet been solved.

\section{PREVIOUS RESEARCH}

This region has been observed by a great number of researchers. D'Orbigny, a french geologist, described Cenozoic sediments of Paraná in his "Voyage dans l'Amérique Meridionale" 1826-1833 (D'ORBIGNY, 1842). He also undertook paleontologic studies and in collaboration with Laurillard, he defines three formations: Guaranftica, Patagónica and Pampeana. Later on, DARWIN (1838), BRAVARD (1858), BURMEITER (1859) and STELZNER (1879) carried out other valuable studies on stratigraphy and paleontology in the province of Entre Rios.

In 1880, Ameghino became interested in the study of mesopotanic mammal fossils from Paraná, since he observed a collection gathered by Scalabrini, who described new species of Taxodonts, genus of dolphins, whales, etc. He considered that the communication between North and South America was interrupted towards the end of the Pliocene and was re-established only in recent times (AMEGHINO, $1880,1921)$.

BONAREL \& NÁGERA (1913) reinterpreted D'Orbigny's observations and from those readings, they concluded that there existed two facies: the Correntina Facies (the Tertiary Guarainien of D'Orbigny) and Entrerriana Facies (the Tertlary Patagonien of D'Orbigny). Each of these facles represent a lower sandy level, a calcareous level and an upper clay level with gypsum content.

WINDHAUSER (1931) undertook research on Cenozoic sediments in Argentina and, based on data from some water wells, he assessed the Miocene sea extension in the country. He agreed 
with Bonarelli and Nágera on the fact that the Correntina Facies did not lie on the Entrerriana Facies, but that the first facies replaced the second one horizontally towards the North.

In 1921, Frenguelli published an important contribution for a better knowledge of the stratigraphy of Entre Rios, mainly referring to some observations in the surroundings of Paraná City. Frenguelli established the existence of three marine units. He based his study on a previous research work done by DOERING (1882) who introduced the idea of marine transgressions with alternating depositions of sediments of continental origin. Frenguelli named these three transgressions as follows: Marine Paranaense, Marine Entrerrianense, and Marine Rionegrense, separated by two continental units both of Pliocene age. One was called the Mesopotamiense between the Paranaense (Miocene) and the Entrerrianense (Pliocene), and The Continental Rionegrense, between the Entrerrianense and the Rionegrense, considering that there was a hiatus between the Paranaense and the Entrerrianense and assigning the Paranaense a Miocene age and the Entrerrianense a Lower Pliocene age. The hiatus was proposed to be associated with the Andine diastrophic movements, the corresponding regression of the Miocene sea. Later, FRENGUELU (1939) extended his studies to the right margin of the Uruguay river.

BATAGLA (1946) undertook geological studies at different places within the province of Entre Rios, such as Hernandarias and Aldea Brasilera.

CORDINI (1949) published an important contribution for the better knowledge of the Economic Geology of Entre Rios.

DE ALBA (1953) introduced the Ituzaingó Formation for the sands and ochre sandstones which extend along the left margin of Paraná River, between the cities of Paraná and Ituzaingó in the province of Corrientes.

SCARTASCINI (1959) published his observations on the organic calcareous shell bank of Paraná and its surroundings.

HERBST (1971) carried out new geological studies and dealt with paleontology together with ZABERT in 1977.

Other important contributions in paleontology were done by CASTELANOS (1960), REIG (1956), PASCUAL \& BONDESIO (1957), PASCUAL \& ORDEMAN (1973) and CAMACHO (1967).

ROSSI DE GARCIA (1966) published "Contribución al conocimiento de los Ostrácodos de Argentina" (Contribution to the knowledge of Ostracodes in Argentina). The study was based on the analysis of microfossils taken from organic banks in Victoria City, located about $\mathbf{4 0}$ km south of Paraná City. The sediments are considered to be of Miocene age.

Most of the recent geological investigations are by ACEÑOLAZA (1973-1984) and ACEÑOLAZA \& SAYAGO (1980). These authors, basing their studies on REINHART (1976) and ZABERT \& HERBST (1977), considered that the marine fossils from Entre Rios were of Miocene age. According to these authors, the Miocene would be represented by silty clay levels at the bottom of the cliffs and beds of 
parasite Ostrea.

GENTIL \& RIMOLDI (1979) proposed new formational names to the geological units, all from the Cretaceous up to the Holocene epoch.

IRIONDO (1972-1980) carried out research dealing with the geomorphology. BERTOLNI (1980) studied the processes which caused the removal and slumping of Cenozoic sediments on the left margin of Paraná river.

\section{UTHOLOGY AND STRATIGRAPHY}

The stratal sequence in Aldea Brasilera (Cristamine Quarry) is given in Figure 2. The lower level (A) is white sand with quartz content, about $10 \mathrm{~m}$ thick. Towards the bottom it becomes more clayish, although some clay lenses can be seen $7 \mathrm{~m}$ below the top. This level shows diagonal stratification in the upper section. Quartz content is high, and, therefore, it is of great value to the glass industry in the country. Although the predominant colour is white, as indicated, it becomes reddish in the upper section due to iron oxidation. Quartz grains show a good roundness when examined under the microscope.

The silt clay unit (B-D) lies in disconformity over the quartz sand (A) and contains a $0.5 \mathrm{~m}$ thick oyster bank with Ostrea patagonica. It may be deduced that the marine transgression which deposited this oyster bank took place over a short period of time due to the thickness of the oyster bank and because of the fact that the shells of these pelecypods are joined together, which would indicate the sudden death of these organisms.

According to Dr.Arrospide (oral communication) the thickness of the clay bank with $O$. patagonica increases to the south, where up to 8 meters of this marine unit have been detected. Therefore, it may be inferred that the marine contribution (transgression) came from that direction.

After the sea regression, reactivation of erosion processes in the emerging land began and the sandy silt ( $E$ and $F$ ), as well as a greyish fine sand $(G)$ were deposited.

Unit $\mathrm{H}$ is a homogeneous and massive greyish white silt which is separated from unit $\mathrm{G}$ by a calcareous level or carbonate floor.

An environmental continentalization is evident as we go upwards in the sedimentary sequence, although engulfing conditions must have prevailed, at least during deposition of silt (G).

Unit $\mathrm{H}$ ends with a calcareous floor (I) (Different levels of carbonate depositions exist in all the region. They are lenticular and epigenetic deposits which would correspond to carbonate depositions resulting from over-saturated circulating waters.).

On top of the calcareous floor (I), there is a unit made up of silt with $\mathrm{CaCO}_{3}$ precipitations (J). In this level, the material lies in a grill-like pattern which gives the level a distinctive aspect 
LITHOLOGY

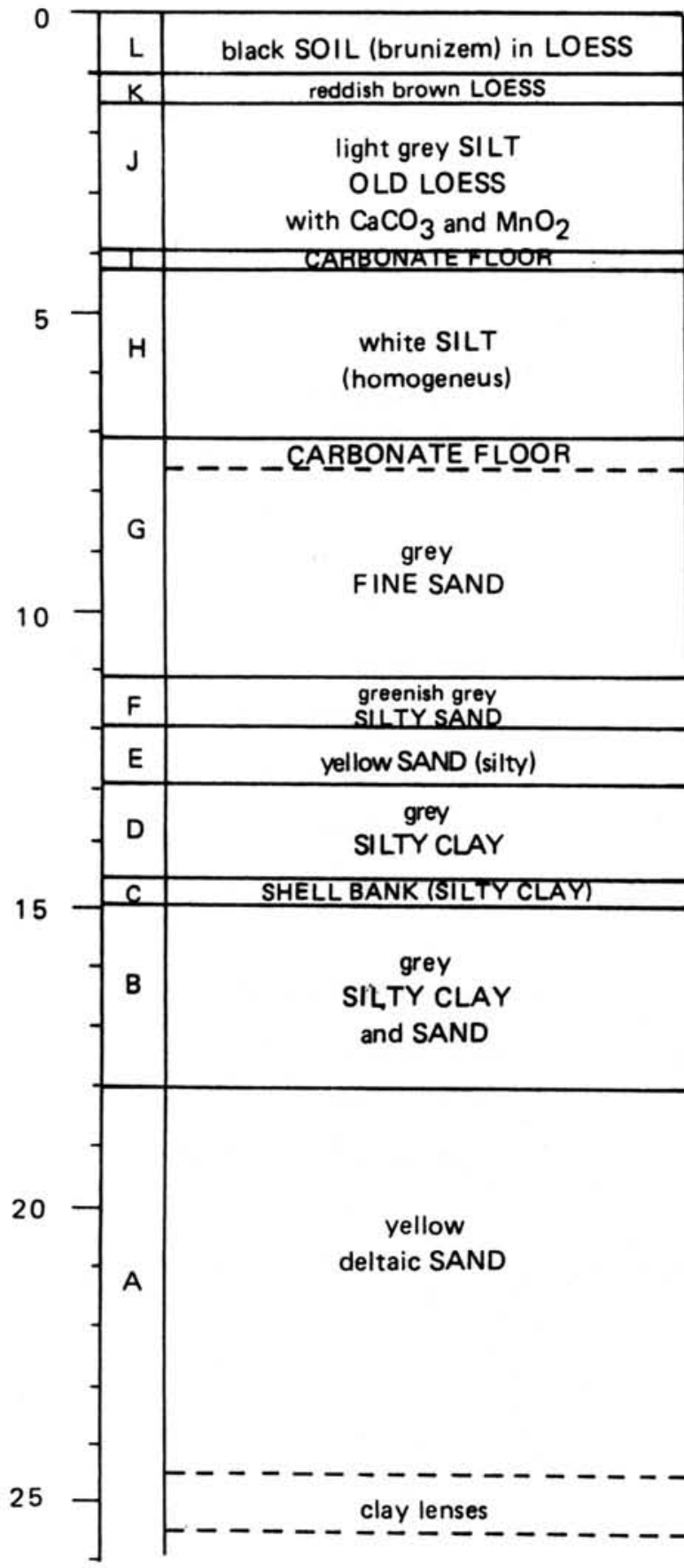

ENVIRONMENT

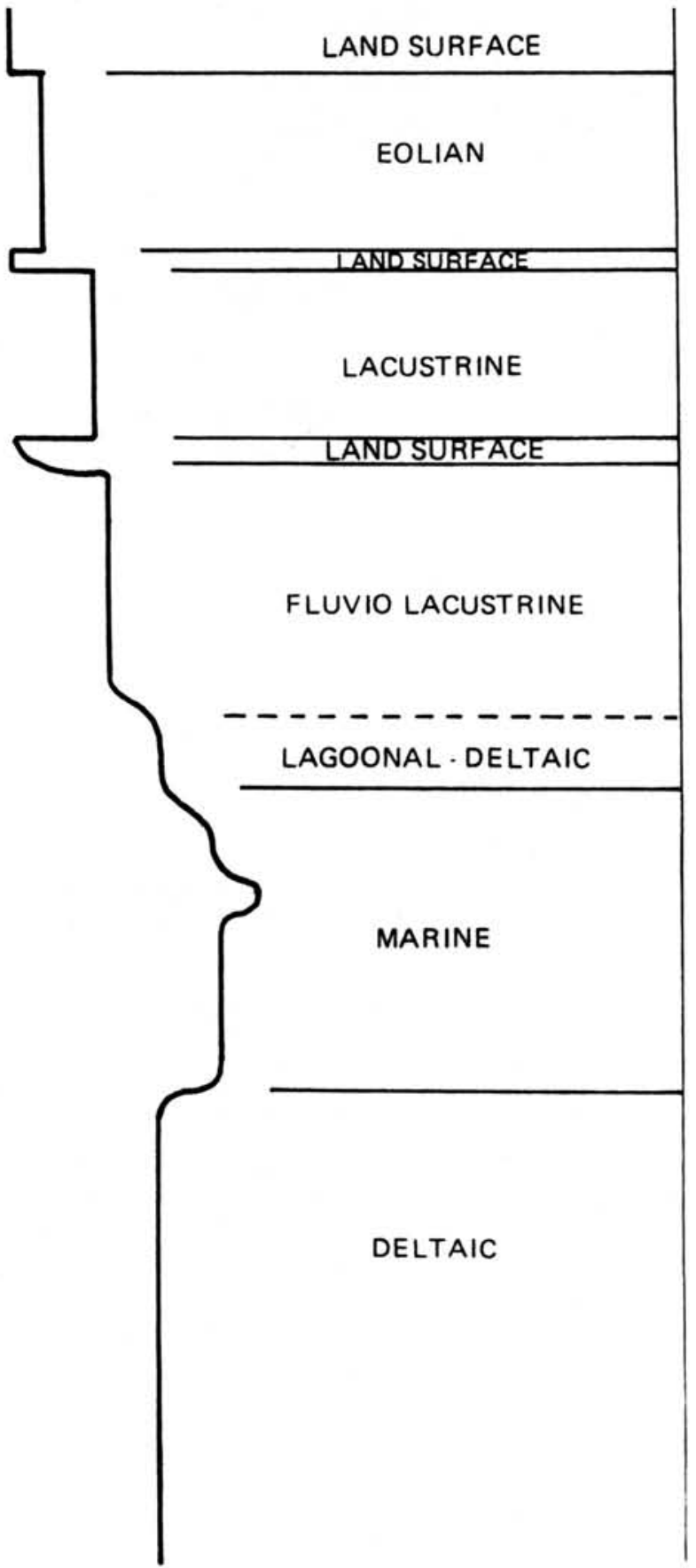

Figure 2 - Lthology of Adea Brasilera geological section. Depth in meters and environment are represented. 
when it is compared to the rest of the exposed units. The average thickness of unit for the area is approximately $4 \mathrm{~m}$. It has been indicated as "old loess" and might have been deposited in a lacustrine environment. It shows $\mathrm{MnO}_{2}$ patches and, in some points, it shows a greenish colour.

The sequence ends with a more powdery loess $(K)$ than the previous one without $\mathrm{MnO}_{2}$ patches, with no calcareous grill-like formations but with carbonate clastic from the preceding unit. This loess-like unit (K) lies in disconformity on level J. The present soil (L), about $0.40 \mathrm{~m}$ thick, is formed in the loess (K) unit.

\section{SAMPLING METHOD}

Oriented samples were taken with the help of a manual square section sampler made of non-magnetic material. They were transfered to plastic cubic boxes of $2 \mathrm{~mm}$ sides. In order to avoid particle movements, a non-magnetic binding material was added (plastic glue).

The paleomagnetic sampling provided a total of 25 reliable sample levels. Four samples from the basal part were added later. The last ones were taken from a clay level included in the underlying sands, shown with A in Figure 2. At least 2 separate samples (sometimes more) were taken from each individual sampling level

\section{PALEOMAGNETIC STUDIES}

Paleomagnetic measurements were performed on an extra sensitive (specially built) Digico Spinner Magnetometer at the Paleomagnetic Laboratory of the University of Stockholm.

NRM for all samples was first measured (29 levels). Low intensities (about $0.1 \times 16^{-6}$ emu) were observed in the basal part of the sequence. These values increase towards the upper loessic material, reaching values of up to $8.4 \times 10^{-6} \mathrm{emu}$ (Fig. 3).

Alternating magnetic field demagnetization was applied in order to remove secondary components of magnetization.

Due to the intensities observed in NRM, low demagnetizing field was used in order to avoid destruction of remanent magnetization. The lowest demagnetization values range was between 25 and $50 \mathrm{Oe}$, and the highest between 550 and 700 Oe peak field.

Figure 4 shows the behaviour of sample 24 when subjected to alternating field demagnetization. Coercive forces range between 150 and $300 \mathrm{Oe}$. All values up to $250 \mathrm{Oe}$, and even 450 Oe, lie well concentrated within a reasonably narrow zone. 


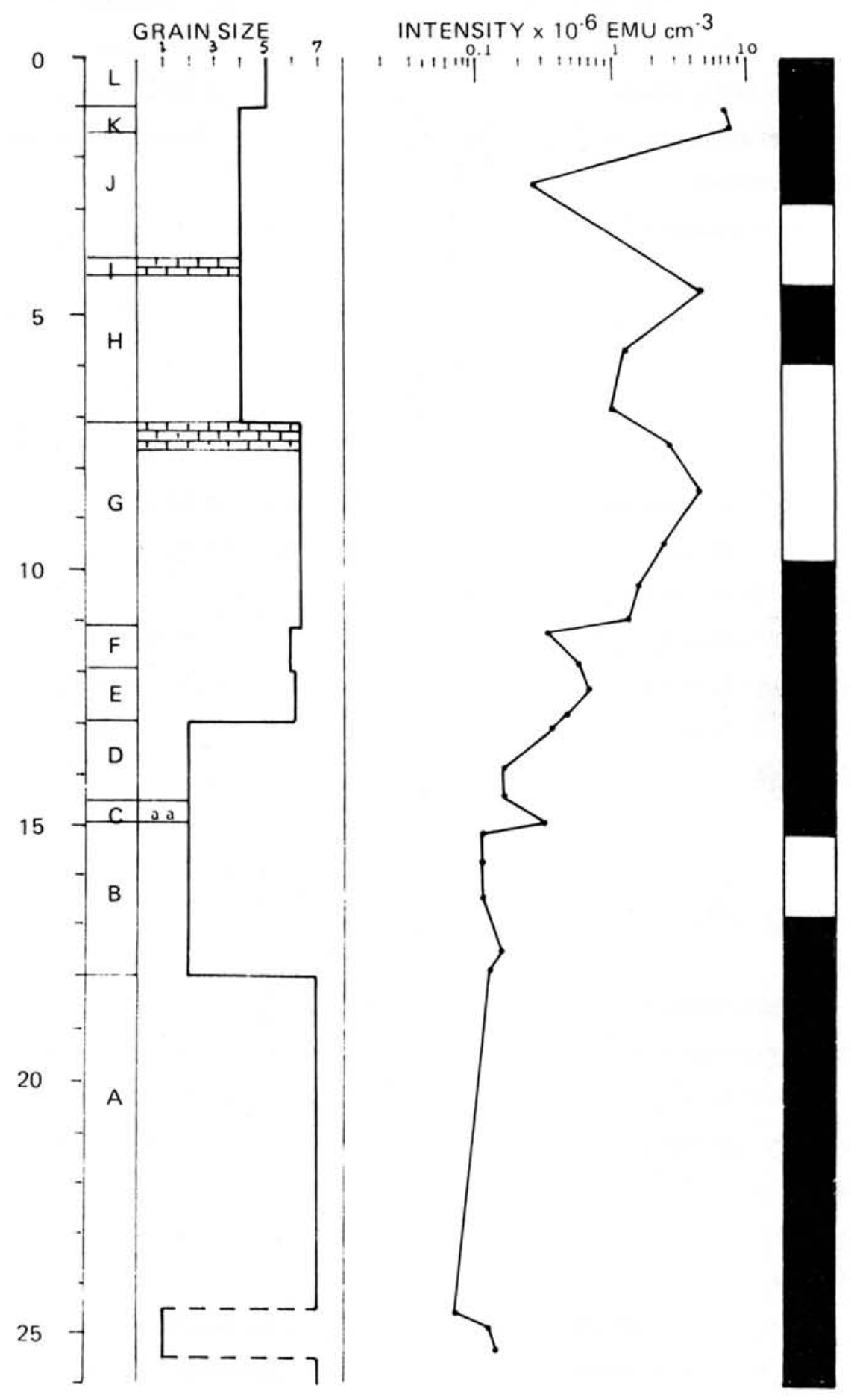

Figure 3 - Grain size distribution: ( 1 = clay, $2=$ silty clay, $3=$ clayey silt, $4=$ silt, $5=$ sandy silt, $6=$ silty sand, $7=$ sand $), N R M$ intensity (increasing upwards) and magnetostratigraphy established (Fig. 5). 


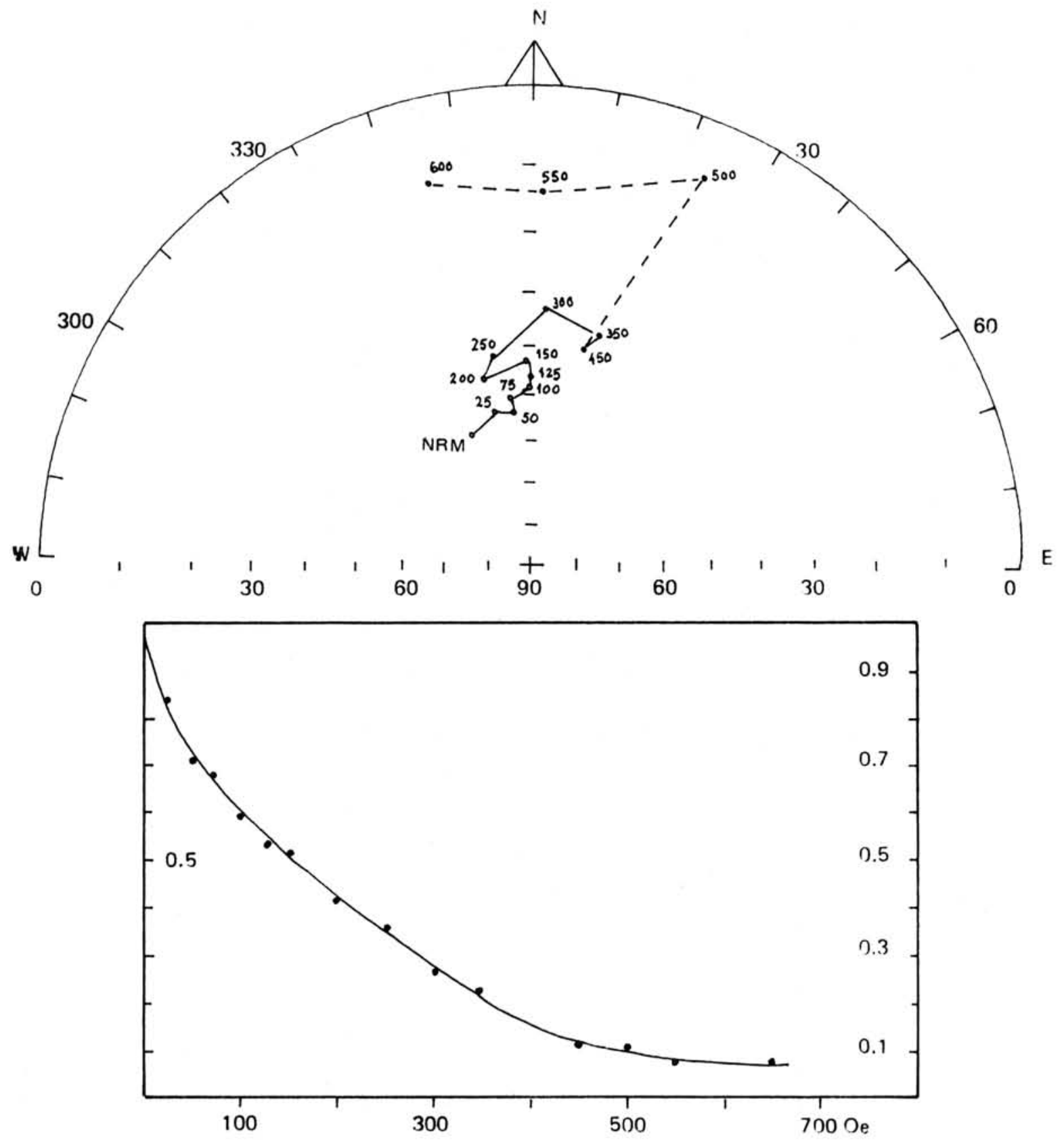

Figure 4 - Sample 24B behaviour when demagnetized. 
Pilot samples were chosen for each of the exposed units in order to find the optimum demagnetizing level for the rest of the samples. The most frequent demagnetization value was 150 Oe. An erratic behaviour was observed in low intensity samples. This is probably due to the destruction of the remanent magnetization when the sample is demagnetized.

Declination and inclination curves are shown in Figure 5, as well as VGP (Virtual Geomagnetic Pole) latitude. Normal polarity has been indicated with black and reversed with white.

In Figure 6, the VGP paths of all six successive reversals have been plotted for comparisons with the study of reversal mechanisms undertaken by FULER et al. (1979). All the six reversals recorded are so-called "far-sited". Further sampling of the reversal intervals will sharpen the picture.

\section{PALEOMAGNETIC RESULTS}

The Paleomagnetic results and the magnetostratigraphy obtained are given in Figure 5. Seven alternating periods of normal and reversed polarity are identified. They are interpreted as representing the period from the Brunhes back to early Gauss.

The Brunhes Normal Polarity Epoch (shown in black) corresponds to the brownish loess bed (K-L) known as "Bonaerense" and the upper part of the "old loess" (J).

The lower part of the "old loess" silt (J), the unit I carbonate floor, the unit $\mathrm{H}$ white silt and the upper part the unit G fine sand (silt) belong to the Matuyama Reversed Polarity Epoch, in the upper part of unit $\mathrm{H}$ broken by a period of normal polarity which we interpret as the Olduvai Normal Polarity Event.

The lower part of unit $G$ down to the base of the sequence (unit $A$ ) is characterized by normal polarity interpreted as the Gauss Normal Polarity Epoch. In unit B, it is broken by a period of reversed polarity, however. We interpret this as the Kaena and/or Mammoth Reversed Polarity Event. Further sampling is needed for the final deciphering of the thin structures of this (these) event(s).

The direct association between the negative polarity event in the unit B silty clay and sand and the Ostrea bank (C) is of great significante, and may serve as a marker constellation. A reversed polarity event in clayey silt below an Ostrea bed has been found also in Molino Doll some $\mathbf{5 5} \mathrm{km}$ towards the southeast. A negative polarity event has also been found in clayey silt below an erosinal hiatus in Puerto Alvear some $10 \mathrm{~km}$ towards the southwest. We believe that they all represent the same polarity event (Kaena and/or Mammoth) and that this event just precedes a short marine transgression maximum which we, therefore, can date to about $2.9 \mathrm{Ma}$.

The deltaic white sand unit (A) was deposited under normal polarity conditions, indicating that it is less than $3.4 \mathrm{Ma}$ old (i.e., the Gauss/Gilbert reversal). 


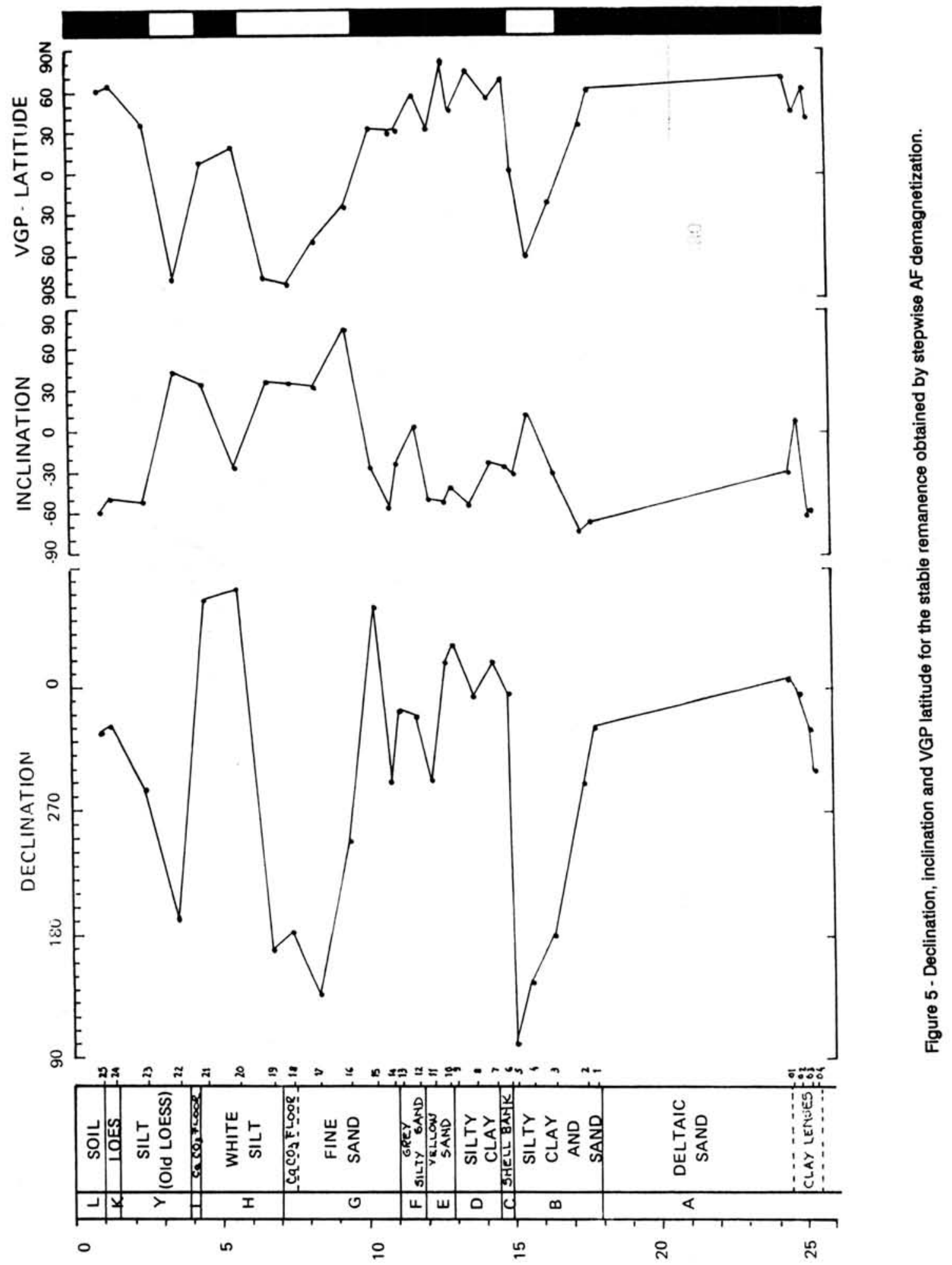




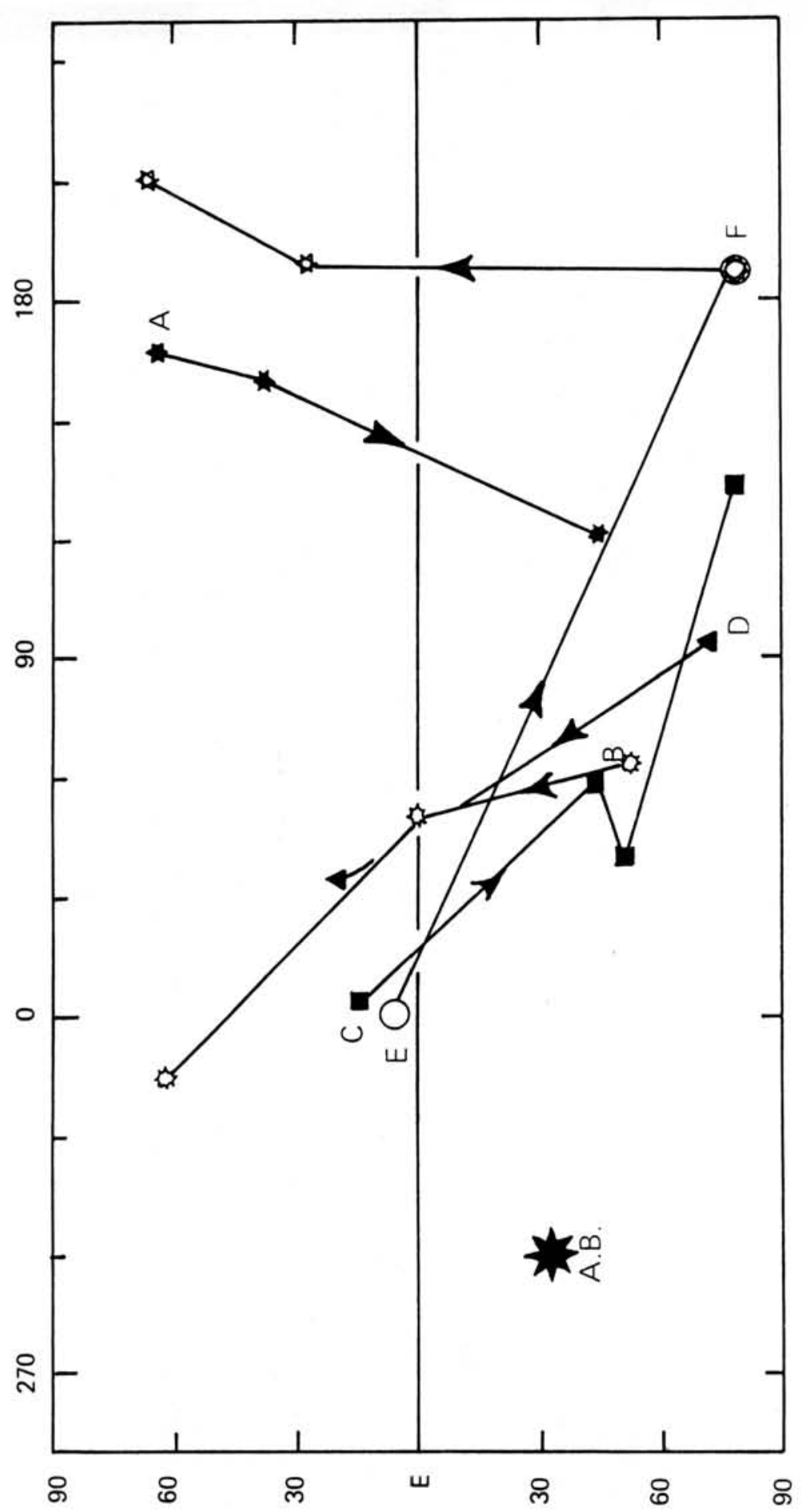

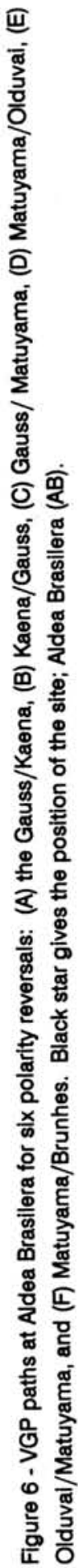


Based on the magnetostratigraphy established (Fig. 5), a time/depth graph has been constructed (Fig. 7) that shows the building up of sediments with time, i.e., a sedimentation rate curve. The deltaic sand unit $(A)$ is a high sedimentation rate deposits. The marine and fluvio-lacustrine beds of units $B$ to $\mathrm{H}$ were laid down at a sedimentation rate in the order of 7-9 mm/1,000 years. When these environmental conditions ended in association with the upper reversal of the Olduval event and the deposition became restricted to eolian loess deposition, the sedimentation rate drastically went down to about $2 \mathrm{~mm} / 1,000$ years.

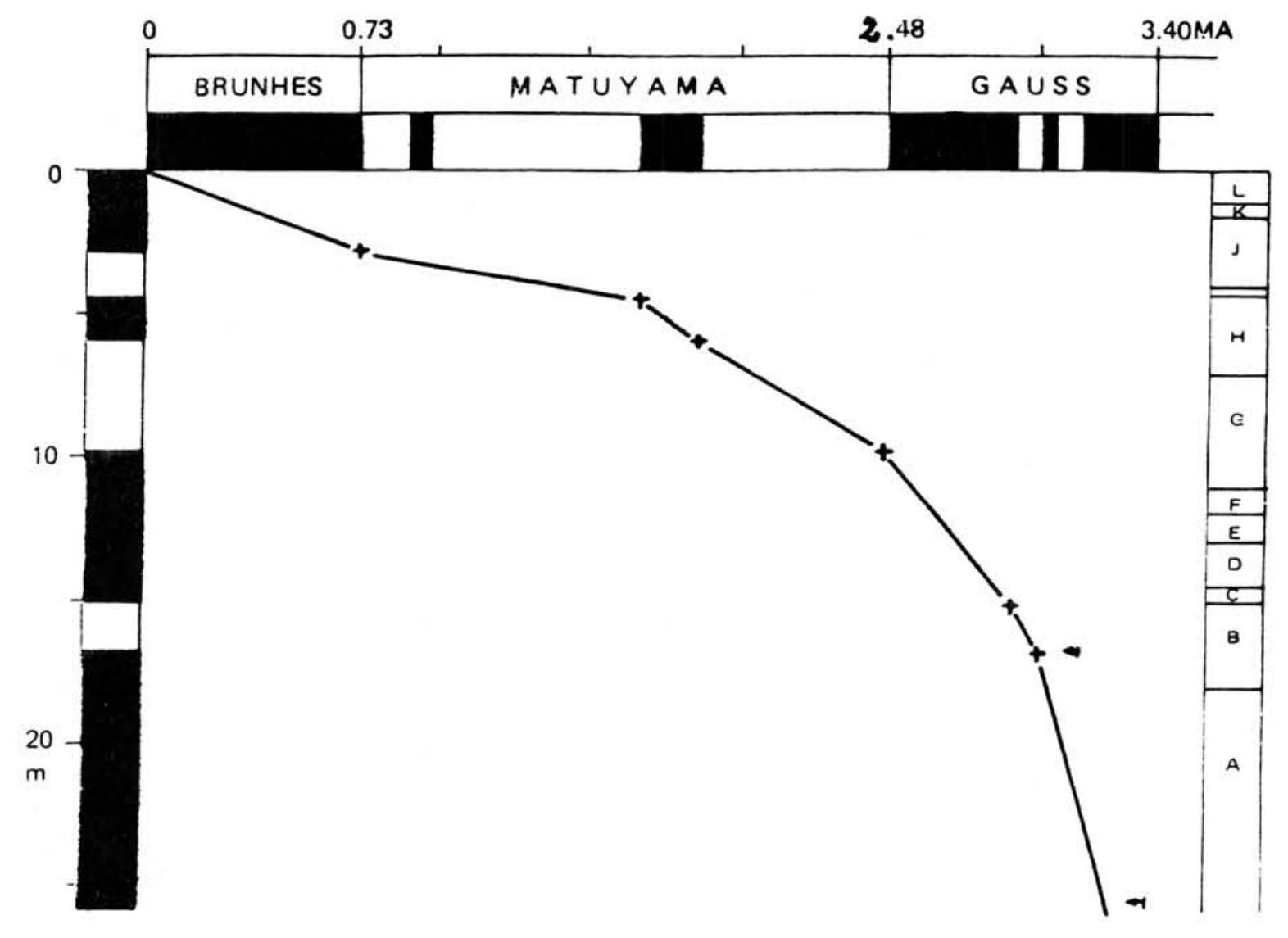

Figure 7 - Time/depth graph utilizing the magnetostratigraphy established (vertical column) and the International Polarity Time Scale (horizontal column). 


\section{DISCUSSION AND CONCLUSIONS}

The paleomagnetic investigation of the sequence at Aldea Brasilera indicates that a marine transgression began during the Kaena Reversed Polarity Event (deposition of unit B silty clay sand above the unit $A$ low-level deltaic sand) and culminated right after this event with the deposition of the unit $C$ Ostrea bank. This implies that the Ostrea bank is about $2.9 \mathrm{Ma}$ old and of Pliocene age.

This does not agree with the opinion of ROSSI DE GARCCA (1966). HERBST (1980) and other researchers who consider that the oyster bank of the region located to the south of Parana City has a Miocene age.

Although the Miocene ingression has a great extension on the present territory of Argentina, reaching up to the Sierras Pampeanas, it is now possible to show that, afterwards and during the general regression of the sea, a minor transgression took place at around $2.9 \mathrm{Ma}$ and gave rise to a littoral and shallow sea with engulfing zones, where sediments and organisms from that sea and the continent were mixed and deposited. This fact would be demonstrated by the existence of fossil levels with shark teeth, whale vertebras and fish mixed up with tree trunks and other organisms of littoral and continental environment.

From the geological observation of Aldea Brasilera section, as well as from natural exposed cross-sections in the cliffs, it is inferred that there existed a certain cyclicity in the sedimentation. This is confirmed by the existence of three main deposition environments which are easily differentiated. After the Miocene sea regression, sand $(A)$ is deposited in a continental-littoral environment. Then a marine environment (transgression) began in the region. In this environment, clayey silts (partly sandy), and shell banks were deposited.

Finally, the continental environment of the Pleistocene-Holocene was established with predominance of eolian activity.

Marine levels mentioned are undoubtedly referred to an overall change in the oceanographic climatic conditions which affected all the Argentinian coast. Rises in marine level do not seem to have been of great significance until approximately $3 \mathrm{Ma}$ ago. This agrees with the analyses on sea changes done by MöRNER (1986).

In the profile of Aldea Brasilera it has also been indicated the existence of a powdery reddish-brown loess $(K)$, below the present soil (brunizem) which has been deposited, covering all the region and in disconformity with the preceding units.

The unit indicated $\mathrm{J}$ has been named "old loess" and it corresponds to the loessic units with the greatest precipitation of $\mathrm{CaCO}_{3}$ in the region. These units have been studied and sampled at other sites due to the general interest in correlating exposed sediments within the research area.

According to MÖRNER \& SYLWAN (1988) and RUOCCO (1988), based on studies of 
sediments from Patagonia and Buenos Aires Province, these loessic deposits would be related to glaciations which occurred in the Andine zone.

\section{ACKNOWLEDGEMENTS}

I am very grateful to the University of Stockholm for the economic support which made this research work possible. I am also very thankful Dr.N.A.Mörner, director of my Ph.D.thesis, who helped me with paleomagnetic sampling in Aldea Brasilera, for his support in the measurements carried out at Stockholm Paleomagnetic Laboratory, and for his assistance with the present paper; to Dr. Urien, for his guidence during my work in Argentina; to Lic.Bertolini and Thomas for their support in the field investigations and to Dr.Arrospide for his observations and communications.

\section{REFERENCES}

ACEÑOLAZA, F.G. (1976) Consideraciones bioestratigráficas sobre el Terciario marino de Paraná y alrededores. Acta Geologica Lilloana, 13(2):91-108.

ACEÑOLAZA, F.G. \& SAYAGO, J.M. (1980) Análisis preliminar sobre la estratigrafia morfodinámica y morfogénesis de la region de Villa Urquiza, provincia de Entre Rios. Acta Geologica Lilloana, 15(2):139-154.

AMEGHINO, F. (1880) La Formación Pampeana y estudio de los terrenos de transporte de la cuenca del Plata. Bs.As.

AMEGHINO, F. (1921) Ancedentes históricos sobre el estudio de las barrancas del Paraná. 16p.

BATTAGLIA, A.A. (1949) Estudio preliminar de las arenas de Entre Rios. Dirección General de Industria Minera, Carpeta 196, Buenos Aires.

BATTAGLIA, A.A. (1961) Estudio geológico del yeso de Hernandarias Dto. de la Paz. Provincia de Entre Rios. Universidad Nacional del Litoral.

BERTOLNI, J.C. (1982) Descripción y clasificación de los movimientos de masa en las barrancas 
Entrerrianas del Rio Paraná, República Argentina. In: CONGRESSO LATINOAMERICANO DE GEOLOGIA, 5., Buenos Aires, 1982. Actas. Buenos Aires. v.4, p.37-52.

BOBBIO, M.L; DEVINCENZI, S.M.; ORGUEIRA, M.J; VALENCIO, D. (1986) La magnetostratigrafia del Ensenadense y Bonaerense de la ciudad de la Plata, su significado geológico. Revista de la Asociación Geológica Argentina, 41(1-2):7-21.

BRAVARD, A. (1857) Monografia de los terrenos marinos terciarios de las cercanias de Paraná. Buenos Aires.

CASTELLANOS, A. (1939) El subsuelo de Rosario. Anales de la Sociedad Cientifica Argentina, 27:

CASTELlanOS, A. (1960) Entre Rios en la Paleontologia Argentina. Direc. de Prensa Cultura y Turismo. Museo de Paraná. Entre Rios.

CORDINI, R. (1949) Contribución al conocimiento de la Geología Económica de Entre Rios. Dirección General de Industria y Mineria Anales, 2:1-78.

CORTELEZZI, C. \& GOMES, V. (1965) Los basaltos tholefticos de la perforación Nogoyá Entre Rios; áplicación de métodos químicos para determinación de $\mathrm{FeO}$ en minerales y rocas. Acta Geológica Lilloana, 6:87-98.

DE ALBA, E. (1953) Geología del Alto Paraná en relación con los trabajos de derrocamiento entre Ituzaingó y Posadas. Revista de la Asociación Geológica Argentina, 8(3):129-161.

DE DIEGO, B.M. (1963) Los terrenos superficiales de la Pampa, clasificación, distribución, cronología. Ministerio de Agricultura y Ganadería de Santa Fé.

DOERING, A. (1882) Informe oficial de la Comisión Cientffica agregada al Estado mayor general de la expedición al Rio Negro (Patagonia) Geologia, 3:299-530.

D'ORBIGNY, A. (1842) Voyage dans l'Amerique meridionale. Vol.III.

FRENGUEШU, J. (1920) Geología de Entre Rios. Boletin de la Academia Nacional de Ciencias, 24(1-2):55256. 
FRENGUEШ, J. (1957) Geografia de la República Argentina. T.II. Tercera parte.

FULLER, M.; WIUAMS, I.; HOFFMAN, K.S. (1979) Paleomagnetic records of geomagnetic field reversals and morphology of the transitional fields. Reviews of Geophysics and Space Physics, 17(2):179203.

GENTIU, C. \& RIMOLDI, H. (1980) Mesopotamia. In: SIMPOSIO DE GEOLOGÍA REGIONAL ARGENTINA, 2., Córdoba, 1979. Actas, Córdoba Academia Nacional de Ciencias. p.185-223.

GROEBER, P. (1961) Contribuciones al conocimiento geológico del delta del Paraná y alrededores. Anales Comisión Investigaciones Cientificas, 2:9-54.

HERBST, R. (1980) Consideraciones estratigráficas y litológicas sobre la Formación Fray Bentos (Oligoceno inf-medio) de Argentina y Uruguay. Revista de la Asociación Geológica Argentina, 35(3):308-317.

MöRNER, N.A. (1986) Global neotectonics, arcs and geoid configuration. In: WEZEL, F.C. (ed.) The origin of arcs. Amsterdam, Elsevier. p.79-91. (Development in Geotectonics, 21).

MöRNER, N.A. \& SYLWAN, C. (1989) Magnetostratigraphy of the Patagonian moraine sequence at Lago Buenos Aires. Journal South American Earth Sciences, 2(4):385-389.

ORGEIRA, M.J. \& VALENCIO, D. (1984) Estudio paleomagnético de los sedimentos asignados al Cenozoico tardío aflorantes en la Barranca de los Lobos. In: CONGRESO GEOLÓGICO ARGENTINO, 9., San Carlos de Bariloche, 1984. Actas. San Carlos de Bariloche, A.G.A., v.4, p.162-173.

PASCUAL, R.; ORTEGA, H.E.J.; GONDAR, D.; TONNI, E. (1965) Las edades del Cenozóico mamalffero de la Argentina con especial atención a aquellas del territorio Bonaerense. Anales de la Comisión de Investigación Cientffica, 6(1):165-193.

READING, H.G. (1978) Sedimentary environments and facies. Oxford, Blackwell. 569p.

ROSSI DE GARCÍA, E. (1966) Contribución al conocimiento de los ostrácodos de la Argentina, Formación Entre Rios, Victória. Revista de la Asociación Geológica Argentina, 21(3):194-208. 
RUSCONI, C. (1965) La ingresión marina belgranense en Belgrano. Anales de la Sociedad Cientffica. Argentina, 119.

RUOCCO, M. (1988) A $3 \mathrm{Ma}$ paleomagnetic record of coastal continental deposits in Argentina. Palaeogeography, Palaeoclimatology, Palaeoecology, 72(1/2):105-114.

STAPPENBECK, R. (1911) Ligeros apuntes sobre el agua subterranea en las llanuras de la República Argentina. Turin.

SCARTASCINI, G. (1959) El Banco de calcáreo organógeno de Paraná. Museo Bernardino Rivadavia, 1(16).

TAUXE, L; TUCKER, P.; PETERSEN, N.P.; LABREQUE, J.L (1983) The magnetostratigraphy of Leg 73 sediments. Palaeogeography, Palaeoclimatology, Palaeoecology, 42(1/2):65-90.

URIEN, C. et al. (1981) The basins of Southeastern South America. Comite Sudamericano Jurasico y Cretásico, 1:45-125.

WINDHAUSEN, A. (1931) Geología Argentina. Buenos Aires, Jacob Peuser. 645p.

ZABERT, LL \& HERBST, R. (1977) Revisión de la microfauna Miocena de la Formación Paraná entre Victoria y Villa Urquiza, Pcia de Entre Rios, Argentina; algunas consideraciones estratigráficas. Facena,1:131-168. 